\title{
The Sabbath as a remedy for human restlessness
}

\begin{abstract}
Author:
Volker Kessler ${ }^{1}$

Affiliation:

${ }^{1}$ Department of Philosophy,

Practical and Systematic

Theology, University of South

Africa, South Africa

Correspondence to:

Volker Kessler

Email:

volker.kessler@acf.de

Postal address:

Furtwänglerstrasse 10, 51643

Gummersbach, Germany

Dates:

Received: 23 June 2010

Accepted: 18 July 2011

Published: 23 Nov. 2012

How to cite this article:

Kessler, V., 2012, 'The

Sabbath as a remedy for

human restlessness', In die

Skriflig/In Luce Verbi 46(2),

Art. \#61, 8 pages. http://

dx.doi.org/10.4102/ids.

v46i2.61
\end{abstract}

Considering that many people today suffer from restlessness, it would be very helpful to remind ourselves of a very old, very simple but very effective remedy: rest on the Sabbath. In the Christian tradition, Sabbath-keeping often only focused on its spiritual aspects. This article has focused on the benefit of rediscovering the gift of the Sabbath as 'a delight to the soul and a delight for the body' (Heschel). It has shown how we can explicitly learn from the Jewish tradition of holistic Sabbath observance. The article consists of four parts: the phenomenon of human restlessness, ten different facets of the Sabbath in the Old Testament, a short section on the history of pro-Sabbath and anti-Sabbath attitudes within the Christian churches and a concluding section about applying the basic principles of the Sabbath in modern life for the sake of a good work-life balance. Examples from the German context are included.

Die Sabbat as kuur teen menslike rusteloosheid. Wanneer die hedendaagse rusteloosheid van mense in ag geneem word, het dit waarde om onsself aan ' $n$ baie ou, eenvoudige dog effektiewe maatreël tot herstel te herinner, naamlik om op die sabbat te rus. In die Christelike tradisie fokus sabbatsonderhouding dikwels slegs op godsdienstige aspekte. Hierdie artikel het gefokus op die wins in die herontdekking van die sabbatsgeskenk as ' $n$ 'behae vir die siel en die liggaam' (Heschel). Dit toon duidelik hoe ons uit die Joodse tradisie van ' $n$ holistiese sabbatsonderhouding kan leer. Die artikel het bestaan uit vier dele, naamlik die verskynsel van menslike rusteloosheid, tien verskillende fasette van die sabbat in die Ou Testament, ' $n$ kort historiese oorsig oor pro- en teen-standpunte van die Christelike kerk ten opsigte van die sabbat, en ten slotte die toepassing van basiese sabbatsbeginsels in die moderne lewe ter handhawing van ' $n$ goeie balans tussen werk en lewe. Voorbeelde uit die Duitse konteks is ook ingesluit.

\section{Introduction}

The intention of this article is to demonstrate how a very old instruction, the Sabbath commandment, might be used as a remedy for the problem of human restlessness in modern industrial societies. Because I live and work in German-speaking countries in Europe this article is especially written from a Germanic-European perspective. Living and working in South Africa or Africa can be very different. On the other hand, my visits to Africa have shown me that especially people in white-collar jobs in Johannesburg, Cape Town, Potchefstroom or Nairobi are struggling with maintaining their work-life balance just as their counterparts in Cologne, Paris or London do.

The structure of this article is a variation of the praxis cycles commonly used in applied theological disciplines such as Practical Theology or Missiology or Ethics (Kritzinger 2002). The praxis cycle of this article consists of three stages:

1. Context analysis: the context-analysis stage deals with the issue of human restlessness within the framework of modern work-life balance.

2. Theological reflection: the theological reflection stage of this article consists of two parts: a study on the Sabbath in the Old Testament and a historical analysis of the Christian Church wrestling with the Sabbath.

3. Planning: this stage is concerned with how to plan the Sabbath in our modern day.

\section{The problem: Human restlessness}

C 2012. The Authors.

Today many people suffer from restlessness. Both employers and clients expect that everything should be done immediately. Mobile technology has exacerbated the situation by creating an expectation that we ought to be available at any place and at any time, 24 hours a day, seven days a week. To solve the problem of restlessness, there is a huge market of expensive seminars 
and books on how to achieve a good 'work-life balance' (see Tempus 2010).

The management author, Secretan (2006:31), has envisioned a holistic lifestyle: a work-life balance without a clear boundary between work and leisure. Of course, this appears attractive if work is fun. As an academic teacher I have the privilege of being paid for doing something I enjoy. On the one hand, Secretan's vision appears quite attractive. Working days will become as enjoyable as Sundays. On the other hand, if every working day resembles a Sunday then every Sunday will resemble a working day. People will be permanently on call. There will be no rest. At any time an important mail or SMS might appear on your PDA and your thoughts will revert to your job again.

Restlessness is not a new phenomenon. The French mathematician and philosopher Blaise Pascal (1995) who was familiar with the French royal court in the 17th century wrote:

I have often said that the sole cause of man's unhappiness is that he does not know how to stay quietly in his room.... That is why men are so fond of hustle and bustle; that is why prison is such a fearful punishment. (pp. 37-38)

Pascal (1995) found that people desire rest, but are at the same time and often unconsciously afraid of rest:

They think they genuinely want rest when all they really want is activity. They have a secret instinct driving them to seek external diversion and occupation, and this is the result of their constant sense of wretchedness. They have another secret instinct, left over from the greatness of our original nature, telling them that the only true happiness lies in rest and not in excitement. These two contrary instincts give rise to a confused plan ... which leads them to seek rest by way of activity and always to imagine that the satisfaction they miss will come to them once they overcome certain obvious difficulties and can open the door to welcome rest. All our life passes in this way: we seek rest by struggling against certain obstacles, and once they are overcome, rest proves intolerable. (pp. 39-40)

This passage reflects a deep insight into human restlessness. Pascal, belonging to the Augustine tradition, sees restlessness as a curse deriving from the Fall. The letter to the Hebrews also links restlessness to a curse, which is reported in Psalm 95:11, 'They shall never enter my rest.' Hebrews 3:11, 18:4-5 quotes this verse four times! By means of this four-fold repetition the author of Hebrews emphasises the danger of missing God's rest. Hebrews 4:4 links this rest to the creation story (Gn 2:2-3), which is typical of Sabbath theology. We follow this link to explore the different facets of the Sabbath in the Old Testament.

\section{Ten facets of the Sabbath in the Old Testament}

The Sabbath is one of the Ten Commandments, but it is more than that. The Old Testament reveals different facets of the Sabbath. This section will describe these different facets in order to motivate people to rediscover the richness of the Sabbath.

\section{How many facets are there?}

The German Old Testament scholar, Wolff (1971), explained five different facets in his sermon about the Sabbath. The Italian Seventh-Day Adventist, Bacchiocchi (1982), listed seven different aspects of the Sabbath. My analysis of the Sabbath in the Old Testament ended up with ten different facets (Kessler 2008:13-35). I will explain the first two facets in depth and will give an overview of the other eight facets.

\section{The Sabbath is a unique day}

The noun Sabbath is derived from the Hebrew verb for 'stop, rest' (Stolz 1995b:864). The Sabbath commandment is listed ten times in the Pentateuch. ${ }^{1}$ A short version is given in Exodus 34:21a: 'Six days you shall labour but on the seventh day you shall rest.'

For most people today a commandment such as, 'You shall not murder' seems to be more important than the Sabbath commandment. Pastor Krüger, a pastor of the mainline Protestant Church of the Rhineland (Germany), would always ask his new confirmation students (age 12 or 13), 'What do you think is the most important commandment, and which one is the least important one?' The answers concerning the most important one differed from class to class. In conversation with Krüger in 2007 concerning the least important commandment, they all agreed that it was the Sabbath commandment.

For Israel, however, the Sabbath commandment was very important. Pars pro toto the Sabbath could stand for the whole law (Neh 9:14). It was unique in those days. As Spier (1992:12-13) points out in his elaborate work on the Jewish Sabbath, every attempt to explain the Jewish Sabbath as an import from another culture, example Babylonia, has been questioned and for good reason. As far as we know, the seventh-day rhythm of rest had no model outside of Israel. For Old Israel the origin of the Sabbath was always clear. It was a special gift from their God Yahweh. An evidence for the importance of the Sabbath commandment can be seen in the number of words used for it in the Decalogue. Although the Decalogue lists 10 commandments, in both versions (Ex 20:2-17; Dt 5:6-21) one third of the words is used for one commandment.

The Sabbath is called a holy day, which is rooted in the creation story, 'And God blessed the seventh day and made it holy (Gn 2:3). The Hebrew word is qadosh, which has connotations with the word separated and not for ordinary use (Eichrodt [1933] 1959:176; Müller 1995:590). The essence of its meaning is that the seventh day should be different from the other days of the week. The Jewish theologian, Heschel ([1951] 2003:xvii),

1.Dressler (1982:24-26). 
emphasises the fact that the first biblical use of the word qadosh is applied to an object of time, not to an object of space. The second object called to be qadosh is the people of Israel (Ex 19:6), and the third object is an object of space, the Tabernacle (Ex 35-40). Heschel ([1951] 2003:xv) concludes from this that 'Judaism is a religion of time aiming at the sanctification of time.' He calls the Sabbath 'a Palace in Time' (Heschel [1951] 2003:1).

This feature turned out to be a special blessing during the many pogroms the Jews had to suffer in their history:

The Sabbath are our great cathedrals; and our Holy of Holies is a shrine that neither the Romans nor the Germans were able to burn. The enemies can destroy places and synagogues but they cannot prevent the Sabbath to come to the people every seventh day (Heschel [1951] 2003:xv). (Note that the author of these sentences had personal experience in the Nazi regime. Born in Warsaw in 1907, Heschel studied and taught in Berlin, which he, being a Polish Jew, had to leave in 1938. His reflections about the Sabbath were published in 1951, six years after the fall of the Nazi regime.)

\section{The Sabbath copies God's rest during creation}

The Exodus version of the Decalogue links the Sabbath commandment (Ex 20:11) to the creation story (Gn 2:2-3). A closer look at Genesis 2:2 reveals a puzzling question. It says, 'God finished his work ... on the seventh day.' Was God's work not finished on the sixth day? 'To say that God finished work on the seventh day might imply that he was working on that day' (Wenham 1987:35). For this reason some translators and commentators corrected Genesis 2:2 by changing seventh to sixth, for example, the Revised English Bible (1990). Wenham sticks to the number seven but uses the pluperfect had finished in order to indicate that there was no work on the seventh day. Some ancient rabbis gave another explanation for the surprising wording in Genesis 2:2. They concluded there was an act of creation on the seventh day: Menuha [rest] was created on the seventh day! An old Midrash explains, 'After the six days of creation what did the universe still lack? Menuha. Came the Sabbath, came menuha, and the universe was complete' (Heschel [1951] 2003:13).

The comment of the German Old Testament scholar, Gerhard von Rad (1992:161), on Genesis 2:2 is similar. God finished his creation by his resting on the seventh day. Resting brings the work of creation to an end. This resting is characterised by joy about the creation, which was declared to be very good (Gn 1:31; cf. Prov 8:30).

One reason for our restlessness today is that we do not take a breather after completing our work. Instead of enjoying our finished work - as God did on the seventh day - we immediately begin a new one. Thus the Sabbath is an opportunity to copy God's joyful resting after creation. 'So I saw that there is nothing better for a man than to enjoy his work, because that is his lot' (Ec 3:22).

\section{The Sabbath is the sign of a special relationship}

According to Ezekiel 20:12, the Sabbath is a sign for the special Covenant between God and Israel. This explains the death penalty for breaking the Sabbath (Ex 31:15b), which appears harsh in our eyes today. But for Israel breaking the Sabbath meant breaking the Covenant and this meant losing God's protection for the whole people.

\section{The Sabbath reminds us of the gift of freedom}

Deuteronomy's version of the Decalogue links the Sabbath commandment to the liberation from Egypt, 'Remember that you were slaves in Egypt and that the LORD your God brought you out of there with a mighty hand and an outstretched arm. Therefore the LORD your God has commanded you to observe the Sabbath day' (Dt 5:15). Thus Sabbath is a symbol of freedom too. Israel was in slavery but is free now and a free man is free from the obligation to work every day. According to Wolff (1981:137), the Sabbath commandment is a shining example of the fact that the Ten Commandments were not meant to be demands but a liberation from demands. The Sabbath is a gift of free time. It is a command to be lazy (Wolff 1971:32).

\section{The Sabbath protects dependant workers and creation}

The Sabbath commandment was not only for the free Israelites but also for their slaves (Dt 5:14). Considering that the Israelites had been slaves themselves they should not ignore the needs of their slaves. Exodus 23:12 reads as if this were indeed the original goal of the Sabbath commandment, 'But on the seventh day do not work, so that your ox and your donkey may rest and the slave born in your household, and the alien as well, may be refreshed'.

On the Sabbath there is no distinction between master and slave, between successful and unsuccessful people. The Sabbath is an embodiment of the belief that all men are equal, 'it is a day of independence of social condition' (Heschel [1951] 2003:21).

\section{The Sabbath is against the senselessness of restless working}

In Exodus 34:21 the commandment 'on the seventh day you shall rest' has an appendix, 'even during the ploughing season and harvest you must rest'. This reveals the human tendency to work without rest, especially in periods overloaded with work. Human beings often fear to miss an opportunity to receive more (see the illustrative manna story in Exodus 16). For students this might translate into 'even in the time of examinations', whilest for academic theologians it might read 'even in the time of lecturing and deadlines of articles'.

\section{The Sabbath gives work a high esteem}

Beginning with the words, 'Six days you shall labour and do all your work' (Ex 20:9; Dt 5:13) the Sabbath law mirrors a high regard for work, which is very typical for Judaism and very different from the Greeks who did not regard physical work with high esteem. In Greek society only the slaves would do physical work, whereas the Old Testament even introduces the Creator-God as a working God (Gn 2:7-8). 


\section{The Sabbath is a celebration for the Lord}

For Israel it was always clear that the Sabbath is not only for resting from work but 'a day of sacred assembly' (Lv 23:3). On the Sabbath, Israel would meet together to praise God, as it is described by Psalm 92, which is a psalm for the Sabbath day.

\section{The Sabbath is a day of delight}

Readers of the New Testament might get the impression that the Sabbath was a burden to the Jewish people. This burden was not by God's intention. It is the result of many added regulations to the Sabbath. God intended the Sabbath to be a day of joy, 'If you call the Sabbath a delight and the LORD's holy day honourable', says Isaiah 58:13.

\section{The Sabbath is a foretaste of the rest to come}

The use of the Hebrew word menuha is not restricted to the Sabbath rest. Menuha also describes the place where people find rest (Stolz 1995a:43). It is often used as a synonym for the Promised Land, Canaan (Dt 12:9). But menuha means more than land, it also means peace from the enemy. In her history, Israel experienced some periods of menuha which peaked under King Solomon (1 Ki 5:5). But Israel lost her menuha and was finally taken into the Babylonian Exile where they longed for a never-ending menuha. Thus each Sabbath became a foretaste of the final menuha in the future kingdom (Is 56-66).

Hebrews 3-4 picks up this Jewish longing for menuha. It claims that Joshua did not bring Israel to the final menuha and concludes, 'There remains, then, a Sabbath-rest for the people of God' (Heb 4:9).

\section{Three millenniums of wrestling with the Sabbath}

In this article I will give a broad overview. Please consult excellent works like Rordorf (1972), Carson (1982a), Spier (1992), and Becker (2006) for detailed historical analysis.

\section{On the Sabbath praxis before and after the exile}

Spier (1992:18) says we do not know very much about the praxis of the Sabbath in Old Israel. From the 8th century BC onwards the prophets mentioned the Sabbath. Amos 8:5-6 warned the cheating tradesmen who could not wait for the end of the Sabbath to continue their betrayal. Both Isaiah 28:12 and Jeremiah 17:21-27 reproached the Israelites for ignoring the Sabbath.

The Babylonian exile changed the lax Sabbath praxis tremendously. Far away from Jerusalem and from God's Land, the Jews could not bring any offering in the Temple. But they could keep the Sabbath! Thus Sabbath-keeping became a focus of their religious efforts. The Levites praised God for the gift of the Sabbath (Neh 9:14). A new male name appeared, Shabbetaj, and about $50 \%$ of the sons born on the Sabbath seemed to bear this new name (Spier 1992:19). The Sabbath became a prominent symbol for Jewish identity.
It was so highly respected that after the prohibition of the Sabbath under Antiochus Epiphanes (2nd century BC) the Maccabees fought for the Sabbath, but not on the Sabbath. They even preferred to be attacked and killed than to profane the Sabbath (1 Macc 2:34-38).

The discovery that Israel's existence stood or fell with the Sabbath initiated a powerful process to define the meaning of Sabbath rest. For example, one of the rules for keeping the Sabbath rest was, 'How many footsteps are allowed on a Sabbath?' This process led to complex systems of Sabbath regulations. Different religious parties ended up with different regulations, sometimes in contradiction to the regulations of the other parties. Spier (1992:24) concludes that there was nothing like the Sabbath praxis during the period of the Second Temple. Thus Jesus could not offend against the Sabbath law but only against different interpretations which were discussed, but which were not generally binding.

\section{Jesus and the Sabbath}

Depending on their Church tradition many Christians believed that Jesus abolished the Sabbath law. Some theologians, for example, the German protestant New Testament scholars Käsemann, Lohse (both in Becker 2006:266-267) and Goppelt (1991:145-146), teach this. A verse such as John 9:16, 'Some of the Pharisees said, "This man is not from God, for he does not keep the Sabbath"' might give evidence to this view (see also Jn 5:18), but both verses only report the view of Jesus' prosecutors. We do not have a saying from Jesus himself indicating that he abolished the Sabbath commandment. On the contrary, in Matthew 5:19 Jesus warns against abolishing the Commandments. For a long time - perhaps because of an anti-Semitic mood in the Christian churches - many commentators of the New Testament focused too intensely on Jesus' opposition against the Sabbath regulations, not taking into account that Jesus never attacked the Sabbath law itself. This created the impression that Jesus had abolished the Sabbath law.

Obviously, the Sabbath question was one of the key struggles between Jesus and the Jewish religious leaders (e.g. Mt 12:1-14; Mk 2:23-3:6; Lk 6:1-11). In one of these conflicts Jesus answered the Pharisees, 'The Sabbath was made for man, not man for the Sabbath. So the Son of Man is Lord even of the Sabbath' (Mk 2:27-28).

The main issue in these controversial discussions is the question of authority. Who has the right of interpretation? Who is the Lord of the Sabbath? In his gospel, Matthew places another saying just before the Sabbath stories:

Come to me, all you who are weary and burdened, and I will give you rest. Take my yoke upon you and learn from me, for I am gentle and humble in heart, and you will find rest for your souls. For my yoke is easy and my burden is light. (Mt 11:28-30)

Rabbi Neusner (Ratzinger 2007:142), in his fictional discussion with Jesus, rightly assumes Jesus' invitation: The Son of Man 
is truly Lord of the Sabbath because the Son of Man is now Israel's Sabbath!

The Catechism of the Catholic Church ([1993] 2011: no. 2173) clearly states that the accusations against Jesus of violating the Sabbath were wrong. It states, 'But Jesus never fails to respect the holiness of this day'. The Protestant British New Testament scholar, Lincoln (1982:345), explains, 'Jesus cut through the complexities of the Pharisaic debates of His time. He kept the Sabbath law but not the Halakic interpretation of it'. When Jesus' disciples plucked corn they did not violate the Torah, but the Halakah only (Carson 1982b:61). The German Protestant theologians Becker (2006:271-273) and Spier (1992:26) agree that Jesus did not abolish the Sabbath commandment; on the contrary he fought for its original meaning and tried to protect it from over-regulation.

\section{The Sabbath and Sunday in the Church}

Today the majority of Christians (except for Seventh-Day Adventists) celebrate Sunday instead of Saturday as the Sabbath, although there is no explicit New Testament instruction to do so. The change from Sabbath to Sunday developed over many centuries.

The Book of Acts and the New Testament letters both report observance of the seventh day (Ac 13:5, 14, 42, 44; 16:13; $17: 2 ; 18: 4 ; 19: 8)$ and observance of the first day, the day of resurrection (Ac 20:7; 1 Cor 16:2). The Pauline corpus contains three verses which might refer to Sabbath observance (Rm 14:5; Gl 4:10-11; Col 2:16-17). ${ }^{2}$ De Lacey (1982:185) also assumes Paul's position, 'He is also quite happy to allow the seventh-day Sabbath to be observed', but he condemns the teaching that Sabbath observance is necessary for salvation.

The Swiss theologian Rordorf (1972) published an exhaustive collection of sources from the first centuries referring to keeping the Sabbath and/or Sunday. Rordorf (1972:XV) concludes that in the first centuries AD we find every possible combination of this. Some Jewish-Christian circles obeyed the Sabbath only, some celebrated the Sabbath and Sunday. In general, the Gentile-Christian circles celebrated Sunday without keeping the Sabbath (and without condemning Sabbath-keeping!). ${ }^{3}$

In the Roman Empire we find both attitudes, that is, sympathy with the celebration of the Sabbath and anti-Semitic mocking against the Sabbath. For example, the Roman philosopher Seneca condemns Sabbath observance as a wasteful practice, leading to the loss of one seventh of people's time (Spier 1992:29). Unfortunately, many church fathers followed this anti-Semitic attitude. According to them the Sabbath commandment does not mean to abstain from work on one day out of seven but to abstain on all days from all sinful acts.

2.But because the word Sabbath is only used in Colossians 2:16 it might be that Romans 14:5 and Galatians 4:10-11 refer to other days of celebration (see De Lacey 1982:180-182 for a detailed discussion).

3.'Perhaps there were some Gentile Christians who kept the Sabbath ... but if so, they found no spokesman whose writings survived' (Bauckham 1982a:269).
For example, Justin says, 'The new law requires you to keep perpetual Sabbath, and you, because you are idle for one day, suppose your are pious ... The Lord our God does not take pleasure in such observance' (Bauckham 1982a:266).

Justin even regarded the Sabbath commandment as a penalty to Israel for erecting the Golden Calf (Rordorf 1972:37). Bauckham (1982a) resumes the critique of the church fathers:

It is entirely clear that for all these writers the literal commandment to rest one day in seven was a temporary ordinance for Israel alone. The Christian fulfils the commandment by devoting all his time to God. ... no writer of this period betrays any thought of its being a provision for needed physical rest. The Jewish form of observance was therefore 'idleness'. (pp. 266-267)

In Christianity there has always been a great fear of being idle. Even in AD 523, two centuries after Constantine's edict, Benedict's Rule laid down that a monk who is not able or not willing to study on the Lord's day should 'be given some work to do, so that he may not be idle' (Regula Benedicti 48:22-23).

Sunday was installed as a day of rest by Constantine's edict on 03 March AD 321 requiring a total public rest from work 'on the most honourable day of the Sun' (Bauckham 1982a:280). Forty years later the Church followed Constantine by commanding the people not to work on Sunday. Sunday finally took over the Sabbath's role (Spier 1992:121-123). The Church now referred to the old Sabbath commandment, which was mocked earlier, in order to justify resting on a Sunday. According to the Catechism of the Catholic Church ([1993] 2011: no. 2175-2176) the Christian Sunday fulfils the Sabbath commandment although it differs from the Sabbath.

A change returned with the Reformation. The reformers interpreted the development of the Catholic Church as a reversion to Jewish legalism. Thus, the reformers were critical about the Sunday observance as being legalistic (Becker 2006:165). Following the anti-Sabbath line of the church fathers, Luther explains the Sabbath commandment in his great catechism (1529): 'As regards this external observance, this commandment was given to the Jews alone. ... This commandment, therefore, according to its gross sense, does not concern us Christians' (Luther 2011, V. Part First. The Third Commandment).

Luther noticed a natural need for rest, but he did not regard this as a fulfilment of the commandment. However, he felt that because there is a physical need for rest it would be convenient to use this day for meeting in the church. According to Luther (2011) this day could be any day in a week, but it would be better to leave it as it is:

But since from of old Sunday has been appointed for this purpose, we also should continue the same, in order that everything be done in harmonious order, and no one create disorder by unnecessary

'In the Institutes and elsewhere Calvin is clearly in agreement with Luther that the rhythm of every seventhday as the day of worship is not divinely given to Christians' (Bauckham 
1982b:317). Neither Luther nor Calvin saw any theological reasons for resting on Sunday (Becker 2006:110). For them resting was not the essence of Sunday sanctification but only a prerequisite for the real Sunday sanctification, which is going to Church and hearing God's word. This is also taught by the Heidelberg Catechism of 1563:

Question 103: What does God require in the fourth commandment? Answer: First, that the ministry of the gospel and the schools be maintained; and that I, especially on the Sabbath, that is, on the day of rest, diligently frequent the church of God, to hear his word, to use the sacraments, publicly to call upon the Lord, and contribute to the relief of the poor. Secondly, that all the days of my life I cease from my evil works, and yield myself to the Lord, to work by his Holy Spirit in me: and thus begin in this life the eternal Sabbath. (Heidelberg Catechism 2011)

The idea of a day of rest for the body is simply ignored in this passage. This attitude of ignoring the Sabbath had and still has great influence in the Protestant churches in Germany (Becker 2006:115, 121). During the beginning of the industrialisation process in the 19th century the labour force had to work on Sundays. It was the trade unions who raised their voice against those exploiting regulations. The German Protestant churches were not concerned about the lack of rest but only about the hindrance to attend the Church service. As mentioned above, still in the 1960s and 1970s the publications of well-known German Protestant New Testament theologians had this anti-Sabbath tone. It is only recently that the German Protestant Churches officially proclaim the benefit of leisure as an essential part of Sunday sanctification, 'Der Sonntag ist als Tag des Gottesdienstes, der Muße und der Besinnung zu erhalten' (EKD 2007).

In England the development was much more pro-Sabbath. When the English church separated from Rome they adopted much of Calvin's theology, but not his teaching on the Sabbath. Different to Luther and Calvin themselves, they regarded the Sabbath commandment as binding for Christians. Thus, a Puritan Sabbath emerged and was exported to New England and other countries (see Spier 1992:127-129; Bauckham 1982b: 321-329) for a detailed discussion).

Considering that this article is a contribution from a German author to a South African journal I want to draw attention to an interesting meeting point between the traditional South African and German positions. When South Africa took over the former German colony, South West Africa (now Namibia), two different Sabbath cultures met (Melber 1994:158-163). In 1921, the South African administrator concluded that the German laws on the Lord's day were too lax. Thus, he signed a stricter version, the 'Lord's Day Observance Proclamation, No. 54 of 1921' (Melber 1994:158). However, 30 years later in 1953, in a report called 'Commission of Enquiry: Sale of Liquor and Desecration of Sunday' (par. 29) states, 'In this territory there is generally speaking a clash between the original German culture and the new Afrikaans culture' (in Melber 1994:162).

\section{Living the Sabbath today}

We have seen that generally speaking the Christian tradition has neglected important parts of the Sabbath. Often,
Christians have practiced the spiritual aspect of keeping the Sabbath whereas the Jewish tradition has always kept a holistic approach in that the Sabbath was seen as a time for both spiritual and physical or social refreshing. An example regarding the physical and the social aspect is the Rabbinic advice for married couples to have sexual intercourse on the Sabbath (Spier 1992:41; Winner 2006:16). ${ }^{4}$

Different countries have different regulations concerning a day of rest (Rinderspacher, Henkel \& Hollbach 1994) and the situation is constantly changing. In Germany, the Sunday rest is even secured by the Grundgesetz [constitution], article 140. Thus, in general, stores are closed on a Sunday (with some exceptions such as airport shops). However, this Sunday law is heavily disputed. Companies fear loss of profit by closing on a Sunday. This fear resembles Seneca's, 'Sabbath keeping means wasting of time, losing one seventh of your life'. The Catholic philosophers Guardini (1992:32) and Spaemann ([1989] 2001:277) rightly argue that a nation loses something by giving up a general day of rest. However, a nationwide Sabbath is also a symbol of freedom from economic pressures, demonstrating that money does not reign supreme.

Independent of the question whether there is a public day of rest or not we need to ask how we should live the Sabbath. In the last decade several Christians in the US published books about rediscovering the Sabbath in their personal life. These include Dawn (1989), a very early book on this topic, then more recently Winner (2006), Baab (2005) and Buchanan (2006). Lauren Winner is a Jewish woman converted to the Catholic faith. Although she confesses a deep love for Jesus Christ, she misses some Jewish traditions and the Sabbath is the tradition she misses the most (Winner 2006:15).

I have received much inspiration about the Sabbath practice from Heschel's volume. In my book (Kessler 2008:35, 93), I listed 16 suggestions for Sabbath practice in addition to the ten facets of the Old Testament Sabbath. These suggestions are meant as general guidelines and not as stipulations for further Sabbath regulations. I summarise five of these suggestions for attaining modern work-life balance below.

\section{Keep the day different}

This is probably the most important suggestion, rooted in the Old Testament command, 'Holy the day'. In other words, we need to separate this day from other days (contrary to Secretan 2006:31 as above). Separating a day requires active planning and structuring. Peter Drucker, the father of modern management theory, rightly points out that the first duty of an effective executive is to structure his or her time (Drucker 1995:47). That does not happen by chance. Effective time management has to be planned. If you do not invest any energy in structuring your week, every day will look the same. ${ }^{5}$

4.There are also more ascetic streams within Judaism who ask to refrain from sexual activities on the Sabbath in order to honour this day (Beer 1908:31).

5.One could also refer to the Second Principle of Thermodynamics. A popular corollary from this physical principle is that every closed system tends to lose order, structure. One has to invest energy into the system in order to increase the order. 


\section{Rest even from spiritual work}

This is advice especially pertains to pastors and theologians active in church work (but not restricted to them). Of course, it is necessary for a pastor to work on Sunday in order to enable Sunday services, but perhaps it is not necessary to work the entire day. Of course, it is necessary to preach in the morning, but is it necessary to discuss church matters after the service, to do 'church politics'? Could these discussions not be moved to another day in the week?

In the German tradition some pastors have the custom of using Monday as the pastor's Sabbath. For example, Pastor Hambrock of the Deutsche Evangelisch-Lutherische Gemeinde in Cape Town tells the visitor on the church site homepage, 'Sprechstunde nach Vereinbarung. Bitte beachten: Montags ist Pastoren-Sonntag' (St. Martini Kirche 2011). However, in praxis, often the pastor's Sabbath does not function because of too many responsibilities (Nordelbisches Missionszentrum 2009).

Von Heyl (2003) demonstrates that many (German) pastors suffer from burnout. I would argue that keeping the Sabbath regularly would be a first step towards burnout prevention.

\section{Rest on the Sabbath as if all your work were done}

In the developed world time-pressure at work is growing. Employees have to work harder and faster than they used to do. The impression is one of never-ending work. A Jewish commentary to Exodus 20:8 says, 'Is it possible for a human being to do all his work in six days? Does not our work always remain incomplete?' What the verse means to convey is that we should rest on the Sabbath as if all our work was done (in Heschel [1951] 2003:23).

In 1947, two years after the end of World War II, the German Catholic philosopher, Pieper ([1948] 2007), published a book about leisure and cult. Germany was destroyed by bombs and people were busy rebuilding houses and factories. Thus Pieper ([1948] 2007:47) starts his book with the question, 'Is this the right time to speak about leisure? Should we not wait until the house is rebuilt?' Pieper's answer is that this new beginning demands an investigation of leisure. If you want to wait for leisure until you have done all your work, it might be too late. Rest as if all your work has been done.

\section{Rest even from the thought of labour}

This radical principle is again illustrated by a Jewish parable:

A pious man once took a stroll in his vineyard on the Sabbath. He saw a breach in the fence, and then determined to mend it when the Sabbath would be over. At the expiration of the Sabbath he decided: since the thought of repairing the fence occurred to me on the Sabbath I shall never repair it.

(Heschel [1951] 2003:23)

This story illustrates a basic truth: thinking about work is already work. Thus, resting from work includes resting from planning the work. Another practical implication of this principle is that we should not call our colleagues on the day of rest in order to discuss the duties of the coming week.

\section{Time for leisure: Having time instead of dissipating time}

In many countries a very special weekend culture has developed (Rinderspacher et al. 1994). Especially in the developed world, some people try to fill their weekend with as many activities as possible. The leisure industry is prospering enormously (Fritschl 2007), but the increase of activities on Sunday contradicts the idea of the Sabbath. The essence of the Sabbath is to have time, not to dissipate time (Heschel [1951] 2003:7). It is an opportunity to do nothing. The Sabbath also offers an opportunity to refresh social relationships and to spend time with our family or friends.

\section{Conclusion}

This article began with a description of human restlessness. The historical analysis demonstrated that, although each Christian tradition celebrates the Lord's day, some important aspects of the Sabbath have been lost. The reflections on the Old Testament and the Jewish tradition should show that it is worth rediscovering the holistic essence of the Sabbath - a day given for refreshing our bodies, our souls and our social life. The article concluded with suggestions for experiencing the Sabbath as a delight (Is 58:13) in a modern day manner, 'a delight to the soul and a delight for the body' (Heschel [1951] 2003:8). My conclusion is that the old Sabbath commandment is a simple but very effective method for healthy work-life balance.

\section{Acknowledgements Competing interests}

The author declares that he has no financial or personal relationship(s) which may have inappropriately influenced him in writing this article.

\section{References}

Baab, L.M., 2005, Sabbath keeping: Finding freedom in the rhythms of rest, Intervarsity Press, Downers Grove, IL.

Bacchiocchi, S., 1982, Divine rest for human restlessness, Advent-Verlag, Hamburg.

Bauckham, R.J., 1982a, 'Sabbath and Sunday in the Post-Apostolic Church', in D.A. Carson (ed.), From Sabbath to Lord's Day: A Biblical, Historical and Theological Investigation, pp. 251-298, Zondervan, Grand Rapids, MI.

Bauckham, R.J., 1982b, 'Sabbath and Sunday in the Protestant tradition', in D.A. Carson (ed.), From Sabbath to Lord's Day: A Biblical, Historical and Theological Investigation, pp. 311-341, Zondervan, Grand Rapids, MI.

Becker, U., 2006, Sabbat und Sonntag: Plädoyer für eine sabbattheologisch begründete kirchliche Zeitpoliti. Neukirchener Verlag, Neukirchen-Vluyn.

Beer, G. (ed.), 1908, Schabbath, Der Mischnatractat 'Sabbat', J.C.B. Mohr, Tübingen.

Buchanan, M., 2006, The Rest of God: Restoring your Soul by restoring Sabbath, W Publishing Group, Nashville, TN.

Calvin, J., 1997, Unterricht in der christlichen Religion, Neukirchener Verlag, Neukirchen-Vluyn.

Carson, D.A. (ed.), 1982a, From Sabbath to Lord's Day: A biblical, historical and theological investigation, Zondervan, Grand Rapids, MI.

Carson, D.A., 1982b, 'Jesus and the Sabbath in the Four Gospels', in D.A. Carson (ed.), From Sabbath to Lord's Day: A biblical, historical and theological investigation, pp. 57-97, Zondervan, Grand Rapids, MI.

Dawn, M., 1989, Keeping the Sabbath wholly: Ceasing, resting, embracing, feasting, Eerdmans, Grand Rapids.

De Lacey, D.R., 1982, 'The Sabbath/Sunday Question and the Law in the Pauline Corpus', in D.A. Carson (ed.), From Sabbath to Lord's Day: A biblical, historical and theological Investigation, pp. 159-195, Zondervan, Grand Rapids, MI.

Dressler, H.H.P., 1982, 'The Sabbath in the Old Testament', in D.A. Carson (ed.), From Sabbath to Lord's Day: A biblical, historical and theological Investigation, pp. 21-41, Zondervan, Grand Rapids, MI. 
Drucker, P., 1995, The effective executive, ECON, Düsseldorf.

Eichrodt, W., [1933] 1959, Theologie des Alten Testaments, Teil 1, 6, Aufl, Stuttgart: E. Klotz, Vandenhoeck \& Ruprecht, Göttingen.

EKD, 2007, Ohne Sonntag gibt es nur noch Werktage, viewed 21 Sept. 2007, from http://www.ekd.de/sonntagsruhe

Fritschl, H., 2007, Freizeitindustrie: Schöne neue Welt, Bilanz, Das Schweizer Wirtschaftsmagazin, 22.6.2007, viewed 04 July 2011, from http://www.bilanz. $\mathrm{ch} /$ invest/freizeitindustrie-schoeneneue-welt

Goppelt, L., 1991, Theologie des Neuen Testaments, 3, Aufl, Vandenhoeck \& Ruprecht, Göttingen.

Guardini, R., 1992, Der Sonntag - gestern, heute und immer, 1, Taschenbuchaufl, Matthias Grünewald-Verlag, Mainz.

Heidelberg Catechism, [1563] 2011, viewed 04 July 2011, from http://www.reformed org/documents

Heschel, A.J., [1951] 2003, The Sabbath: Its meaning for modern man, Shambhala Publishers, Boston.

Kessler, V., 2008, Der Befehl zum Faulenzen, Den Sabbat wiederentdecken, Verlag der Francke Buchhandlung, Marburg.

Kritzinger, J.N.J., 2002, 'A question of mission - A mission of questions', Missionalia 30(1), 144-173.

Lincoln, A.T., 1982, 'From Sabbath to Lord's Day: A biblical and theological Perspective', in D.A. Carson (ed.), From Sabbath to Lord's Day: A biblical, historical and theological investigation, pp. 343-412, Zondervan, Grand Rapids, MI.

Luther, M., 2011, The large Catechism, viewed 05 July 2011, from http://www.iclnet. org/pub/resources/text/wittenberg/luther/catechism/web/cat-05.html

Melber, H., 1994, 'Deutsches Wochenende in Windhoek, Namibia', in J.P. Rinderspacher, D. Henkel \& B. Hollbach (eds.), Die Welt am Wochenende. Entwicklungsperspektiven der Wochenruhetage - ein interkultureller Vergleich, pp. 155-167, SWI Verlag, Bochum.

Müller, H.P., 1995, 'qds heilig', in E. Jenni \& C. Westermann (eds.), Theologisches Handwörterbuch zum Alten Testament Band II, 5. pp. 590-609, Aufl. Gütersloh.

Nordelbisches Missionszentrum, 2009, Breklumer Auszeit - Ein gestalteter PastorInnen Sonntag, viewed 01 July 2011, from http://www.nmz-mission.de/de.contact/ one.adressen/one.event/index.html? entry=page.event.kd.1126000380.26.e

Pascal, B., 1995, Pensées, Penguin, London.

Pieper, J., [1948] 2007, Leisure: The Basis of Culture, Kösel, München.

Ratzinger, J. [Benedict XVI], 2007, Jesus von Nazareth, Basel \& Wien, Herder, Freiburg.
Regula Benedicti, n.d., The Rule of Benedict, viewed 16 January 2012, from http:// www.osb.org/rb/text/

Rinderspacher, J.P., Henkel, D. \& Hollbach, B. (eds.), 1994, Die Welt am Wochenende, Entwicklungsperspektiven der Wochenruhetage - ein interkultureller Vergleich, SWI Verlag, Bochum.

Rordorf, W., 1972, Sabbat und Sonntag in der Alten Kirche, Theologischer Verlag, Zürich.

Secretan, L., 2006, Inspire! What Great Leaders Do, J. Kamphausen, Bielefeld.

Spaemann, R., [1989] 2001, 'Der Anschlag auf den Sonntag', in R. Spaemann (ed.), Grenzen, Zur ethischen Dimension des Handelns, pp. 273-280, Klett-Cola, Stuttgart.

Spier, E., 1992, Der Sabbat, 2nd edn., Institut Kirche und Judentum, Berlin.

St. Martini Kirche, 2011, St. Martini Kirche Kapstadt, Deutsche Evangelisch-Lutherische Gemeinde im Zentrum Kapstadts, viewed 01 July 2011, from http://www.stmartini.co.za/index.php?idcatside8

Stolz, F., 1995a, 'Nuah ruhen', in Jenni, E. Jenni \& C. Westermann (eds.), Theologisches Handwörterbuch zum Alten Testament Band II, 5, p. 43-46, Aufl, Gütersloh.

Stolz, F., 1995b, 'sbt aufhören, ruhen', in E. Jenni \& C. Westermann (eds.), Theologisches Handwörterbuch zum Alten Testament Band II, 5, pp. 836-870, Aufl, Gütersloh.

Tempus, 2010, Tag der Gelassenheit, viewed 30 March 2010, from http://www.tag der-gelassenheit.de

Vatican, [1993] 2011, Catechism of the Catholic Church, viewed 04 July 2011, from http://vatican.va/archive/ENG0015/_INDEX.HTM

Von Heyl, A., 2003, Zwischen Burnout und spiritueller Erneuerung: Studien zum Beruf des evangelischen Pfarrers und der evangelischen Pfarrerin, Peter Lang, Frankfurt.

Von Rad, G., [1933] 1971, 'Es ist noch eine Ruhe vorhanden dem Volke Gottes', in G. Von Rad (ed.), Gesammelte Studien zum Alten Testament, pp. 101-108, Chr. Kaiser, München.

Von Rad, G., 1992, Theologie des Alten Testament, Band 1, 10th edn., Chr. Kaiser, München.

Wenham, G., 1987, Genesis 1-15, Word Biblical Commentary No. 1, Word Publ, Waco. Winner, L.F., 2006, Sabbat im Café, Gütersloher Verlagshaus, Gütersloh.

Wolff, H.W., 1971, Menschliches, Vier Reden über das Herz, den Ruhetag, die Ehe und den Tod, Chr. Kaiser, München.

Wolff, H.W., 1981, Anthropologie des Alten Testaments, 2nd edn., SCM Press, London. 